\title{
Penerapan Metode VlseKriterijumska Optimizacija I Kompromisno Resenje (VIKOR) dalam Pemilihan Air Conditioner Terbaik
}

\author{
Mesran*, Kurnia Ulfa, Dito Putro Utomo, Ida Rizky Nasution \\ Program Studi Teknik Informatika, STMIK Budi Darma, Medan, Indonesia \\ Email: 1," mesran.skom.mkom@gmail.com, ${ }^{2}$ kurniaulfa82@gmail.com, ${ }^{3}$ ditoputro12@gmail.com \\ 4idarizkynst@gmail.com,
}

\begin{abstract}
Abstrak
Indonesia merupakan salah satu negara yang beriklim tropis yang terdiri dari musim panas dan musim hujan. Pada saat musim panas suhu ruangan akan tinggi, sehingga akan mengakibatkan orang yang berada didalam ruangan tersebut akan merasa tidak nyaman atau kepanasan. Untuk menciptakan kondisi yang nyaman maka diperlukan adanya pendingin ruangan. SPK merupakan bagian dari sistem informasi yang berbasis komputer. Terdapat beberapa tahapan dalam sistem pendukung keputusan yaitu mendefinisikan masalah, pengumpulan data yang relevan dan sesuai, pengolahan data menjadi informasi, dan menentukan alternatif solusi. Banyaknya produk AC yang terdapat di pasaran membuat masyarakat merasa kesulitan dalam memilih AC yang tepat sehingga dibuatlah suatu sistem pendukung keputusan. Metode VIKOR fokus pada perankingan dan memilih dari satu set sampel dengan kriteria yang saling bertentangan, yang dapat membantu para pengambil keputusan untuk mendapatkan keputusan.
\end{abstract}

Kata Kunci : SPK, Metode Vikor, Air Conditioner.

\begin{abstract}
Indonesia is a tropical country which consists of summer and rainy season. During the summer the room temperature will be high, so that will cause people who are in the room will feel uncomfortable or hot. To create comfortable conditions, air conditioning is needed. SPK is part of a computer-based information system. There are several stages in the decision support system, namely defining the problem, collecting relevant and appropriate data, processing data into information, and determining alternative solutions. The number of AC products on the market makes people feel difficult in choosing the right AC so that a decision support system is made. The VIKOR method focuses on ranking and choosing from a set of samples with conflicting criteria, which can help decision-makers to get a decision.
\end{abstract}

Keywords: DSS, Vikor Method, Air Conditioner 


\section{Pendahuluan}

\subsection{Latar Belakang Masalah}

Air Conditioner pendingin ruangan atau yang lebih dikenal dengan sebutan AC merupakan suatu mesin yang digunakan untuk mendinginkan ruangan dengan cara mensirkulasikan gas refrigerant yang berada di pipa dan ditekan serta dihisap oleh kompresor. Pendingin ruangan ini sudah menjadi kebutuhan bagi setiap orang, terutama wilayah yang memiliki musim panas berkepanjangan. AC biasanya terpasang di dalam bangunan besar, seperti perkantoran, hotel, rumah, laboratorium, dan supermarket. Selain sebagai alat pendingin ruangan, AC juga berfungsi untuk menetralisir udara yang masuk dalam ruangan tersebut. Bahkan, ada beberapa jenis AC yang dilengkapi fitur untuk menyerap kuman atau bakteri.

AC dapat memberikan rasa nyaman bagi manusia, dan menghilangkan bau akibat keringat yang mengalir disaat kita sibuk melakukan aktifitas sehari-hari serta meningkatkan efektifitas dalam bekerja. Banyaknya kekeliruan dalam membeli AC merupakan salah satu masalah yang sangat sulit dihindari, sedikitnya pemahaman mengenai AC menjadikan tidak sedikit orang lebih memilih asal beli Dari hasil penelitian, menurut beberapa pendapat dari sebagian konsumen yang sudah membeli AC merasa dirugikan dalam hal ini, karena AC yang dibeli tidak ada jangka satu tahun AC sudah minta diservis, walaupun adanya masa garansi 1 tahun (gratis) tidak menjamin AC tersebut bagus seterusnya, Pemilihan $\mathrm{AC}$ yang tepat dapat memberikan kepuasan tersendiri bagi para pengguna $\mathrm{AC}$, karena jenis $\mathrm{AC}$ yang semakin bervariasi, dari harga, model dan kualitas, dan AC bukanlah barang yang murah untuk dibeli secara berulang dan akan dipakai dalam jangka waktu yang lama.

Dalam menentukan pilihan yang terbaik dan sesuai dengan yang diinginkan konsumen dapat menggunakan sistem pendukung keputusan untuk menemukan hasil dalam memecahkan suatu masalah berdasarkan kriteria yang telah ditentukan, sistem ini sangat membantu dalam pemilihan suatu produk dengan mutu dan kualitas yang terbaik. Adapun sistem yang diterapkan menggunakan metode untuk menganalisa dalam pengambilan keputusan yaitu seperti, VlseKriterijumska Optimizacija Kompromisno Resenje(VIKOR), Technique for Order Preference by Similarity to Ideal Solution(TOPSIS), Elimination and Choice Translation Reality(ELECTRE), Weight Product(WP), Weighted Sum Model(WSM), Preference Ranking Organization for Enrichment Evaluation(PROMETHEE), Simple Multi-Attribute Rating Technique(SMART)[1]-[4].

Banyak penelitian saat ini yang memberikan hasil berupa keputusan terbaik yang bertujuan untuk membantu manajer dalam menghasilkan keputusan. Dodi Siregar pada tahun 2017 melakukan penelitian bahwa penerapan metode VIKOR mampu menyelesaikan berbagai jenis masalah[5]. Mesran dalam penelitian sebelumnya menggunakan metode VIKOR untuk menentukan karyawan yang akan diberikan insentif kerja[4]. Yan JB B Parrangan menggunakan metode VIKOR untuk menentukan kelulusan pembelajaran Sidi pada tahun 2018[6].

Penerapan sistem pendukung keputusan yang dibuat menggunakan metode VIKOR dapat membantu para pengambil keputusan dalam melakukan perankingan nilai masing-masing alternatif solusi[7], [8]. Dari penjelasan di atas, penulis memilih metode VIKOR dikarenakan metode ini mampu memecahkan permasalahan keputusan dengan kriteria yang saling bertentangan dan dari unit yang berbeda, dengan asumsi bahwa kompromi dapat diterima sebagai resolusi dari konflik yang ada. Vikor melakukan perangkingan terhadap alternatif dan menentukan solusi yang mendekati solusi kompromi ideal[9], [10].

\section{Kajian Literatur Dan Pengembangan Hipotesis}

\subsection{Air Conditioner}

Air Conditioner (AC) yang merupakan pendingin dalam ruangan, teknologi Air Conditioner adalah teknologi terbaik dalam kategori pendingin udara dimana suhunya bisa diatur dengan bebas sesuai dengan kebutuhan, udara Air Conditioner juga dapat memasuki seluruh ruang yang ada dalam ruangan tersebut, dan teknologi Air Conditioner sudah memiliki sensor kontrol sendiri yaitu mengontrol suhu panas ruangan dan akan langsung mengaktifkan Air Conditioner tersebut dan mengeluarkan suhu yang sesuai dengan panas ruangan tersebut. Besar satuan Air Conditioner yang digunakan adalah satuan PK (Paard Kracht) yang setara dengan 18000 BTU/hr (British Thermal Unit). Suhu yang optimal akan memberikan pengaruh positif bagi kesehatan dan penghematan. 


\subsection{Sistem Pendukung Keputusan}

Konsep Sistem Pendukung Keputusan (SPK) pertama kali diperkenalkan pada awal tahun 1970-an oleh Michael S. Scott Morton dengan istilah Management Decision System[11]. SPK merupakan sistem interaktif yang berbasis komputer bertujuan untuk membantu pengambil keputusan dalam hal ini manajer dalam memanfaatkan data serta model. Penggunaan sistem pendukung keputusan untuk menyelesaikan masalah-masalah yang tidak terstruktur[12]-[16].

\subsection{Metode VlseKriterijumska Optimizacija I Kompromisno Resenje (VIKOR)}

VIKOR berasal dari kata VlseKriterijumska Optimizacija I Kompromisno Resenje yang merupakan metode analisis pengambilan keputusan dengan Multi Atribut Decision Making (MADM) yang dikembangkan oleh Serafim Opricovic untuk memecahkan permasalahan keputusan dengan kriteria yang saing bertentangan dan dari unit yang berbeda, dengan asumsi bahwa kompromi dapat diterima sebagai resolusi dari konflik yang ada[6], [17], [18]. Pengambil keputusan menginginkan solusi yang mendekati ideal dan setiap alternatif dievaluasi sesuai dengan kriteria yang telah ditetapkan. VIKOR melakukan perangkingan terhadap alternatif dan menentukan solusi yang mendekati solusi kompromi ideal.

Metode VIKOR fokus pada perankingan dan memilih dari satu set sampel dengan kriteria yang saling bertentangan, yang dapat membantu para pengambil keputusan untuk mendapatkan keputusan akhir. Metode ini sangat berguna pada situasi dimana pengambil keputusan tidak memiliki kemampuan untuk menentukan pilihan pada saat disain sebuah sistem dimulai[19], [20].

Langkah-langkah penyelesaian menggunakan metode VIKOR[5], [21], [22], yaitu:

1. Normalisasi Matriks Keputusan

$\mathrm{r}_{\mathrm{ij}}=\left(\frac{X j+-X i j}{X j+-X j-}\right)$

Keterangan:

$x_{i j}=$ Nilai dari dari matriks pengambilan keputusan

$x_{j}{ }^{+}=$Nilai terbaik dalam satu kriteria

$x j^{-}=$Nilai terburuk dalam satu kriteria

2. Menghitung Nilai $\mathrm{S}$ dan $\mathrm{R}$

$\mathrm{S}_{\mathrm{i}}=\sum_{j=1}^{n} W j\left(\frac{X j+-X i j}{X j+-X j-}\right)$

$w_{j}=$ bobot kriteria

Nilai S didapatkan dari penjumlahan hasil perkalian bobot kriteria dengan data pada setiap sampel.

$\mathrm{R}_{\mathrm{i}}=\operatorname{Max} \mathrm{j}\left[\mathrm{w}_{\mathrm{j}}\left(\frac{X j+-X i j}{X j+-X j-}\right)\right]$

Nilai R: adalah nilai terbesar dari perkalian bobot kriteria dengan data normalisasi dari setiap sampel.

3. Menghitung indeks VIKOR

$\mathrm{Q}_{\mathrm{i}}=\left[\frac{\mathrm{Si}-\mathrm{S}+}{S--S+}\right] \mathrm{V}+\left[\frac{\mathrm{Ri}-\mathrm{R}+}{R--R+}\right](1-\mathrm{V})$

Keterangan:

$\mathrm{S}+=$ nilai $\mathrm{S}$ terkecil

$\mathrm{S}-\mathrm{=}$ nilai $\mathrm{S}$ terbesar

$\mathrm{R}+=$ nilai $\mathrm{R}$ terkecil

$\mathrm{R}$ - = nilai R terbesar

Untuk nilai v yaitu konstanta dengan nilai 0.5, sampel dengan nilai Q terkecil merupakan sampel terbaik.

3. Metode Penelitian

Pada tahapan penelitian ini penulis membagi tahapan kedalam beberapa bagian, yaitu:

a. Tahapan Identifikasi dan Analisa Masalah

b. Tahapan Studi Literatur

c. Tahapan Penerapan Metode VIKOR

d. Tahapan Pengujian 
e. Tahapan Kesimpulan

Tahapan diatas dapat dilihat pada gambar berikut ini.

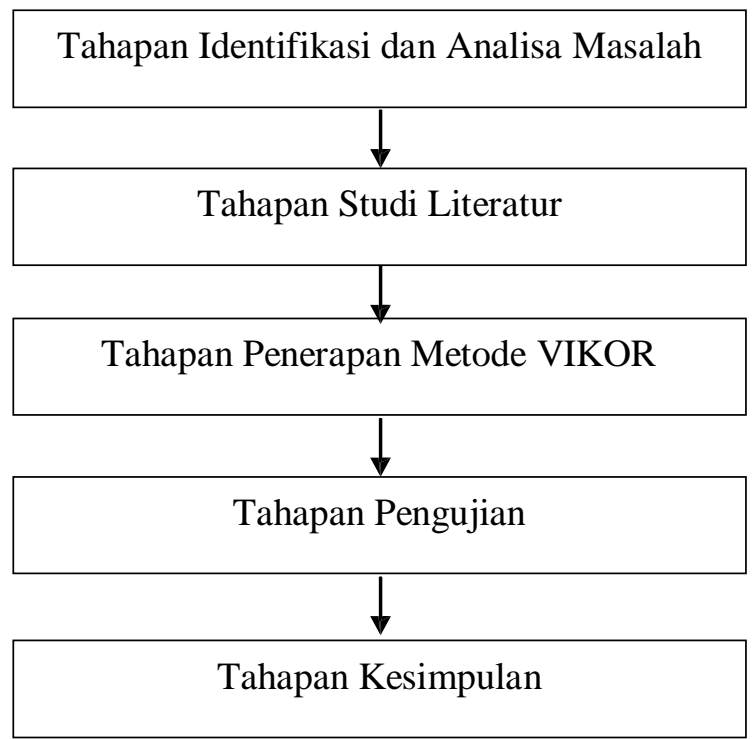

Gambar 3.1 Tahapan Penelitian

\section{Hasil dan Pembahasan}

Sistem pendukung keputusan pemilihan AC terbaik merupakan suatu sistem yang dibuat untuk memenuhi kualitas yang diinginkan konsumen dalam pemilihan AC terbaik serta memberikan hasil yang akurat dalam pemilihan AC terbaik. Dalam sistem pendukung keputusan pemilihan AC terbaik ini adalah untuk membantu konsumen menemukan AC terbaik sesuai dengan yang diinginkan konsumen. Analisa masalah dilakukan untuk mendapatkan gambaran secara lengkap mengenai permasalahan konsumen dalam menentukan AC terbaik.

Kegiatan memilih AC yang terbaik merupakan kegiatan yang dilakukan oleh konsumen. Namun, memilih AC yang tepat sesuai dengan kebutuhan serta kualitas yang terbaik bukan hal mudah. Banyaknya pilihan tersedia bisa jadi membuat bingung dalam memilihnya. Jenis-jenis AC mempunyai persyaratan untuk tujuan pemakaian tertentu. Dalam pemilihan AC terbaik model Fuzzy Multiple Attribute Decision Making(FMADM) dengan metode Vise Kriterijumska Optimizacija Kompromisno Resenje, maka diperlukan kriteria-kriteria dan bobot untuk melakukan proses perhitungannya sehingga akan didapat alternatif terbaik, dalam penelitian ini alternatif yang dimaksud penulis adalah merek AC yang dipilih.

\subsection{Kriteria dan Bobot}

Dalam tahapan ini dibutuhkan kriteria yang akan dijadikan bahan perhitungan pada proses pemilihan AC terbaik. Hal tersebut dimaksud untuk menentukan AC mana yang akan terpilih sebagai $\mathrm{AC}$ yang baik untuk digunakan. Adapun kreteria yang dibutuhkan sebagai bahan pertimbangan oleh pelanggan dapat dilihat pada tabel 4.1 berikut ini.

Tabel 4.1 Tabel Kriteria

\begin{tabular}{|c|l|c|}
\hline Kriteria & \multicolumn{1}{|c|}{ Keterangan } & Bobot \\
\hline $\mathrm{C}_{1}$ & Harga & $0.30 \%$ \\
\hline $\mathrm{C}_{2}$ & Quick Cooling (Kecepatan Dingin) & $0.25 \%$ \\
\hline $\mathrm{C}_{3}$ & Pemakaian Daya Listrik (Watt) & $0.18 \%$ \\
\hline $\mathrm{C}_{4}$ & Garansi & $0.12 \%$ \\
\hline $\mathrm{C}_{5}$ & BTU/h & $0,10 \%$ \\
\hline $\mathrm{C}_{6}$ & Berat AC+Kompressor(kg) & $0,05 \%$ \\
\hline
\end{tabular}


Tabel 4.2 Merk yang tersedia

\begin{tabular}{|c|c|c|c|c|c|c|c|}
\hline No & Merk AC & $\mathrm{C}_{1}$ & $\mathrm{C}_{2}$ & $\mathrm{C}_{3}$ & $\mathrm{C}_{4}$ & $\mathrm{C}_{5}$ & $\mathrm{C}_{6}$ \\
\hline 1 & LG T05NLA & Rp 2.999.000 & Cepat & $\begin{array}{l}395 \\
\text { watt }\end{array}$ & 1 thn & 4.600 & 30 \\
\hline 2 & $\begin{array}{c}\text { PANASONIC } \\
\text { PN05RKJ }\end{array}$ & Rp 2.803.000 & Cepat & $\begin{array}{l}380 \\
\text { watt }\end{array}$ & 1 thn & 5.000 & 30 \\
\hline 3 & SHARP A5MEY & Rp 2.999.000 & Lama & $\begin{array}{l}390 \\
\text { watt }\end{array}$ & 1 thn & 5.000 & 18,5 \\
\hline 4 & $\begin{array}{c}\text { SAMSUNG } \\
\text { AR05HCFLAW }\end{array}$ & Rp 2.999.000 & Cepat & $\begin{array}{l}350 \\
\text { watt }\end{array}$ & 1 thn & 5.000 & 50 \\
\hline 5 & $\begin{array}{c}\text { TAC } \\
\text { 09CS/BYTCL }\end{array}$ & Rp 2.650.000 & Cepat & $\begin{array}{l}900 \\
\text { watt }\end{array}$ & 1 thn & 9.000 & 30 \\
\hline 6 & $\begin{array}{c}\text { DAIKIN } \\
\text { FTNE15JEV }\end{array}$ & Rp 2.853.000 & Cepat & $\begin{array}{l}340 \\
\text { watt }\end{array}$ & 1 thn & 5.000 & 30 \\
\hline 7 & $\begin{array}{c}\text { POLYTRON } \\
\text { NEUVA ICE PAC } \\
\text { 05VX }\end{array}$ & Rp 2.575.000 & Lama & $\begin{array}{l}440 \\
\text { watt }\end{array}$ & 2 thn & 4.610 & 31 \\
\hline 8 & $\begin{array}{c}\text { MITSUBISHI } \\
\text { SRK-05CMP-3 }\end{array}$ & Rp 2.799.000 & Sedang & $\begin{array}{l}380 \\
\text { watt }\end{array}$ & 1 thn & 5.000 & 50 \\
\hline
\end{tabular}

Pada pembobotan untuk tiap-tiap kriteria ditentukan dari tingkat kepentingan dari masing-masing kriteria. Tingkat kepentingan tertinggi terdapat pada kriteria harga dan kecepatan dingin (quick cooling), kemudian kriteria pemakaian daya listrik dan garansi AC memiliki tingkat kepentingan kedua dan BTU/h setara dengan berat AC beserta kompressornya. Berdasarkan dari nilai bobot terhadap kepentingan dari masing-masing kriteria maka bobot awal untuk masing-masing kriteria $\left(\mathrm{C}_{1}-\mathrm{C}_{6}\right)$ dari setiap alternatif dapat dilihat pada tabel 4.3 berikut.

Tabel 4.3 Menentukan Kriteria Harga AC

\begin{tabular}{|l|c|c|}
\hline \multicolumn{1}{|c|}{ Harga } & Bilangan Fuzzy & Nilai \\
\hline$<1.500 .000$ & Sangat baik & 50 \\
\hline $1.500 .000-1.999 .000$ & Baik & 40 \\
\hline $2.000 .000-2.499 .000$ & Cukup & 30 \\
\hline $2.500 .000-2.999 .000$ & Buruk & 20 \\
\hline$\geq 3.000 .000$ & Sangat Buruk & 10 \\
\hline
\end{tabular}

Tabel 4.4 Menentukan Kriteria (kecepatan dinginnya) quick cooling

\begin{tabular}{|l|c|c|}
\hline \multicolumn{1}{|c|}{ Quick Cooling } & Bilangan Fuzzy & Nilai \\
\hline$<1$ menit (Cepat) & Baik & 40 \\
\hline$>2$ menit (Sedang) & Cukup & 30 \\
\hline$>=5$ menit (Lama) & Buruk & 20 \\
\hline
\end{tabular}

Tabel 4.5 Menentukan Kriteria Pemakaian Daya Listrik

\begin{tabular}{|c|c|c|}
\hline Pemakaian Daya (watt) & Bilangan Fuzzy & Nilai \\
\hline$<200$ & Sangat Baik & 50 \\
\hline $200-290$ & Baik & 40 \\
\hline $300-390$ & Cukup & 30 \\
\hline $400-490$ & Buruk & 20 \\
\hline$\geq 500$ & Sangat Buruk & 10 \\
\hline
\end{tabular}

Tabel 4.6 Menentukan Kriteria Garansi

\begin{tabular}{l|l|l} 
Pemakaian Daya & Bilangan Fuzzy & Nilai
\end{tabular}




\begin{tabular}{|c|c|c|}
\hline$<6$ bulan & Sangat Buruk & 10 \\
\hline 6 bulan -1 tahun & Buruk & 20 \\
\hline$\geq 1$ tahun & Cukup & 30 \\
\hline
\end{tabular}

Tabel 4.7 Menentukan Kriteria BTU/h

\begin{tabular}{|c|c|c|}
\hline Kapasitas (BTU/h) & Bilangan Fuzzy & Nilai \\
\hline$<3.000$ & Sangat Baik & 50 \\
\hline $3.000-3.999$ & Baik & 40 \\
\hline $4.000-4.999$ & Cukup & 30 \\
\hline
\end{tabular}

Tabel 4.8 Menentukan Kriteria BTU/h lanjutan

\begin{tabular}{|c|c|c|}
\hline Kapasitas (BTU/h) & Bilangan Fuzzy & Nilai \\
\hline $5.000-5.999$ & Buruk & 20 \\
\hline$\geq 6.000$ & Sangat Buruk & 10 \\
\hline
\end{tabular}

Tabel 4.9 Menentukan Kriteria Berat AC+Kompressor (kg)

\begin{tabular}{|c|c|c|}
\hline Berat (kg) & Bilangan Fuzzy & Nilai \\
\hline$<30$ & Sangat Baik & 50 \\
\hline $30-39$ & Baik & 40 \\
\hline $40-49$ & Cukup & 30 \\
\hline $50-59$ & Buruk & 20 \\
\hline$\geq 60$ & Sangat Buruk & 10 \\
\hline
\end{tabular}

Berikut dibawah ini adalah tabel penentuan kode setiap data alternatif AC.

Tabel 4.10 Alternatif

\begin{tabular}{|c|l|}
\hline Alternatif & \multicolumn{1}{|c|}{ Alternatif } \\
\hline $\mathrm{A}_{1}$ & LG T05NLA \\
\hline $\mathrm{A}_{2}$ & PANASONIC PNO5RKJ \\
\hline $\mathrm{A}_{3}$ & SHARP A5MEY \\
\hline $\mathrm{A}_{4}$ & SAMSUNG AR05HCFLAW \\
\hline $\mathrm{A}_{5}$ & TAC 09CS/BYTCL \\
\hline $\mathrm{A}_{6}$ & DAIKIN FTNE15JEV \\
\hline $\mathrm{A}_{7}$ & POLYTRON NEUVA ICE PAC 05VX \\
\hline $\mathrm{A}_{8}$ & MITSUBISHI SRK-05CMP-3 \\
\hline
\end{tabular}

Dari tabel diatas, maka dapat ditentukan rating kecocokan antara alternatif dan kriteria seperti yang terlihat pada tabel berikut ini.

Tabel 4.11 Rating Kecocokan Dari Setiap Alternatif Pada Setiap Kriteria

\begin{tabular}{|l|c|c|c|c|c|c|}
\hline \multirow{2}{*}{\multicolumn{1}{c|}{ Alternatif }} & \multicolumn{7}{|c|}{ Kriteria } \\
\cline { 2 - 8 } & $\mathrm{C}_{1}$ & $\mathrm{C}_{2}$ & $\mathrm{C}_{3}$ & $\mathrm{C}_{4}$ & $\mathrm{C}_{5}$ & $\mathrm{C}_{6}$ \\
\hline LG T05NLA & 20 & 40 & 30 & 20 & 30 & 40 \\
\hline PANASONIC PN05RKJ & 20 & 40 & 30 & 20 & 20 & 40 \\
\hline SHARP A5MEY & 20 & 20 & 30 & 20 & 20 & 50 \\
\hline SAMSUNG AR05HCFLAW & 20 & 40 & 30 & 20 & 20 & 20 \\
\hline TAC 09CS/BYTCL & 20 & 40 & 10 & 20 & 10 & 40 \\
\hline DAIKIN FTNE15JEV & 20 & 40 & 30 & 20 & 20 & 40 \\
\hline POLYTRON NEUVA ICE PAC 05VX & 20 & 20 & 20 & 30 & 30 & 40 \\
\hline MITSUBISHI SRK-05CMP-3 & 20 & 30 & 30 & 20 & 20 & 20 \\
\hline
\end{tabular}




\subsection{Penerapan Menggunakan Metode VIKOR}

Pada bagian dibawah ini merupakan tahapan-tahapan dalam menghasilkan keputusan terbaik dengan menggunakan metode VIKOR (VIseKriterijumska Optimizacija 1 Kompromisno Resenje), yaitu:

1. Menetapkan matriks keputusan

$$
X=\left[\begin{array}{llllll}
20 & 40 & 30 & 20 & 30 & 40 \\
20 & 40 & 30 & 20 & 20 & 40 \\
20 & 20 & 30 & 20 & 20 & 50 \\
20 & 40 & 30 & 20 & 20 & 20 \\
20 & 40 & 10 & 20 & 10 & 40 \\
20 & 40 & 30 & 20 & 20 & 40 \\
20 & 20 & 20 & 30 & 30 & 40 \\
20 & 30 & 30 & 20 & 20 & 20
\end{array}\right]
$$

2. Normalisasi matriks keputusan, dengan menggunakan persamaan 1.

Dari matrik keputusan, setiap kriteria akan dilakukan normalisasi data seperti dibawah ini.

a. Kriteria untuk C1

$$
\begin{aligned}
& \mathrm{R}(\mathrm{A} 1), \mathrm{C} 1=\frac{(20-20)}{(20-20)}=\frac{0}{0}=0 \\
& \mathrm{R}(\mathrm{A} 2), \mathrm{C} 1=\frac{(20-20)}{(20-20)}=\frac{0}{0}=0 \\
& \mathrm{R}(\mathrm{A} 3), \mathrm{C} 1=\frac{(20-20)}{(20-20)}=\frac{0}{0}=0 \\
& \mathrm{R}(\mathrm{A} 4), \mathrm{C} 1=\frac{(20-20)}{(20-20)}=\frac{0}{0}=0 \\
& \mathrm{R}(\mathrm{A} 5), \mathrm{C} 1=\frac{(20-20)}{(20-20)}=\frac{0}{0}=0 \\
& \mathrm{R}(\mathrm{A} 6), \mathrm{C} 1=\frac{(20-20)}{(20-20)}=\frac{0}{0}=0 \\
& \mathrm{R}(\mathrm{A} 7), \mathrm{C} 1=\frac{(20-20)}{(20-20)}=\frac{0}{0}=0 \\
& \mathrm{R}(\mathrm{A} 8), \mathrm{C} 1=\frac{(20-20)}{(20-20)}=\frac{0}{0}=0
\end{aligned}
$$

b. Kriteria Untuk C2

$$
\begin{aligned}
& \mathrm{R}(\mathrm{A} 1), \mathrm{C} 2=\frac{(40-40)}{(40-20)}=\frac{0}{20}=0 \\
& \mathrm{R}(\mathrm{A} 2), \mathrm{C} 2=\frac{(40-40)}{(40-20)}=\frac{0}{20}=0 \\
& \mathrm{R}(\mathrm{A} 3), \mathrm{C} 2=\frac{(40-20)}{(40-20)}=\frac{20}{20}=1 \\
& \mathrm{R}(\mathrm{A} 4), \mathrm{C} 2=\frac{(40-40)}{(40-20)}=\frac{0}{20}=0 \\
& \mathrm{R}(\mathrm{A} 5), \mathrm{C} 2=\frac{(40-40)}{(40-20)}=\frac{0}{20}=0 \\
& \mathrm{R}(\mathrm{A} 6), \mathrm{C} 2=\frac{(40-40)}{(40-20)}=\frac{0}{20}=0 \\
& \mathrm{R}(\mathrm{A} 7), \mathrm{C} 2=\frac{(40-20)}{(40-20)}=\frac{20}{20}=1 \\
& \mathrm{R}(\mathrm{A} 8), \mathrm{C} 2=\frac{(40-30)}{(40-20)}=\frac{10}{20}=0,5 \\
& \mathrm{c} . \mathrm{Kriteria} \mathrm{Untuk} \mathrm{C} 3 \\
& \mathrm{R}(\mathrm{A} 1), \mathrm{C} 3=\frac{(30-30)}{(30-10)}=\frac{0}{20}=0 \\
& \mathrm{R}(\mathrm{A} 2), \mathrm{C} 3=\frac{(30-30)}{(30-10)}=\frac{0}{20}=0 \\
& \mathrm{R}(\mathrm{A} 3), \mathrm{C} 3=\frac{(30-30)}{(30-10)}=\frac{0}{20}=0 \\
& \mathrm{R}(\mathrm{A} 4), \mathrm{C} 3=\frac{(30-30)}{(30-10)}=\frac{0}{20}=0 \\
& \mathrm{R}(\mathrm{A} 5), \mathrm{C} 3=\frac{(30-10)}{(30-10)}=\frac{20}{20}=1
\end{aligned}
$$


$\mathrm{R}(\mathrm{A} 6), \mathrm{C} 3=\frac{(30-30)}{(30-10)}=\frac{0}{20}=0$
$\mathrm{R}(\mathrm{A} 7), \mathrm{C} 3=\frac{(30-20)}{(30-10)}=\frac{10}{20}=0$,
$\mathrm{R}(\mathrm{A} 8), \mathrm{C} 3=\frac{(30-30)}{(30-10)}=\frac{0}{20}=0$
$\mathrm{~d} . \mathrm{Kriteria} \mathrm{Untuk} \mathrm{C} 4$
$\mathrm{R}(\mathrm{A} 1), \mathrm{C} 4=\frac{(30-20)}{(30-20)}=\frac{10}{10}=1$
$\mathrm{R}(\mathrm{A} 2), \mathrm{C} 4=\frac{(30-20)}{(30-20)}=\frac{10}{10}=1$
$\mathrm{R}(\mathrm{A} 3), \mathrm{C} 4=\frac{(30-20)}{(30-20)}=\frac{10}{10}=1$
$\mathrm{R}(\mathrm{A} 4), \mathrm{C} 4=\frac{(30-20)}{(30-20)}=\frac{10}{10}=1$
$\mathrm{R}(\mathrm{A} 5), \mathrm{C} 4=\frac{(30-20)}{(30-20)}=\frac{10}{10}=1$
$\mathrm{R}(\mathrm{A} 6), \mathrm{C} 4=\frac{(30-20)}{(30-20)}=\frac{10}{10}=1$
$\mathrm{R}(\mathrm{A} 7), \mathrm{C} 4=\frac{(30-30)}{(30-20)}=\frac{0}{10}=0$
$\mathrm{R}(\mathrm{A} 8), \mathrm{C} 4=\frac{(30-20)}{(30-20)}=\frac{10}{10}=1$

e. Kriteria Untuk C5

$$
\begin{aligned}
& \mathrm{R}(\mathrm{A} 1), \mathrm{C} 5=\frac{(30-30)}{(30-10)}=\frac{0}{20}=0 \\
& \mathrm{R}(\mathrm{A} 2), \mathrm{C} 5=\frac{(30-20)}{(30-10)}=\frac{10}{20}=0,5 \\
& \mathrm{R}(\mathrm{A} 3), \mathrm{C} 5=\frac{(30-20)}{(30-10)}=\frac{10}{20}=0,5 \\
& \mathrm{R}(\mathrm{A} 4), \mathrm{C} 5=\frac{(30-20)}{(30-10)}=\frac{10}{20}=0,5 \\
& \mathrm{R}(\mathrm{A} 5), \mathrm{C} 5=\frac{(30-10)}{(30-10)}=\frac{20}{20}=1 \\
& \mathrm{R}(\mathrm{A} 6), \mathrm{C} 5=\frac{(30-20)}{(30-10)}=\frac{10}{20}=0,5 \\
& \mathrm{R}(\mathrm{A} 7), \mathrm{C} 5=\frac{(30-30)}{(30-10)}=\frac{0}{20}=0 \\
& \mathrm{R}(\mathrm{A} 8), \mathrm{C} 5=\frac{(30-20)}{(30-10)}=\frac{10}{20}=0,5 \\
& \mathrm{f} . \mathrm{Kriteria} \mathrm{Un} \operatorname{tuk} \mathrm{C6} \\
& \mathrm{R}(\mathrm{A} 1), \mathrm{C} 6=\frac{(50-40)}{(50-20)}=\frac{10}{30}=0,333 \\
& \mathrm{R}(\mathrm{A} 2), \mathrm{C} 6=\frac{(50-40)}{(50-20)}=\frac{10}{30}=0,333 \\
& \mathrm{R}(\mathrm{A} 3), \mathrm{C} 6=\frac{(50-50)}{(50-20)}=\frac{0}{30}=0 \\
& \mathrm{R}(\mathrm{A} 4), \mathrm{C} 6=\frac{(50-20)}{(50-20)}=\frac{30}{30}=1 \\
& \mathrm{R}(\mathrm{A} 5), \mathrm{C} 6=\frac{(50-40)}{(50-20)}=\frac{10}{30}=0,333 \\
& \mathrm{R}(\mathrm{A} 6), \mathrm{C} 6=\frac{(50-40)}{(50-20)}=\frac{10}{30}=0,333 \\
& \mathrm{R}(\mathrm{A} 7), \mathrm{C} 6=\frac{(50-40)}{(50-20)}=\frac{10}{30}=0,333 \\
& \mathrm{R}(\mathrm{A} 8), \mathrm{C} 6=\frac{(50-20)}{(50-20)}=\frac{30}{30}=1 \\
& \mathrm{D}
\end{aligned}
$$

Dengan langkah-langkah perhitungan di atas, maka didapatkan data normalisasi semua sampel. Berikut disajikan data normalisasi semua sampel (normalisasi matriks). 
Tabel 4.12 Normalisasi Matriks

\begin{tabular}{|c|c|c|c|c|c|c|c|}
\hline \multirow{2}{*}{ No } & \multirow{2}{*}{ Alternatif } & \multicolumn{7}{|c|}{ Kriteria } \\
\cline { 3 - 8 } & & $\mathrm{C}_{1}$ & $\mathrm{C}_{2}$ & $\mathrm{C}_{3}$ & $\mathrm{C}_{4}$ & $\mathrm{C}_{5}$ & $\mathrm{C}_{6}$ \\
\hline 1 & $\mathrm{~A}_{1}$ & 0 & 0 & 0 & 1 & 0 & 0,333 \\
\hline 2 & $\mathrm{~A}_{2}$ & 0 & 0 & 0 & 1 & 0,5 & 0,333 \\
\hline 3 & $\mathrm{~A}_{3}$ & 0 & 1 & 0 & 1 & 0,5 & 0 \\
\hline 4 & $\mathrm{~A}_{4}$ & 0 & 0 & 0 & 1 & 0,5 & 1 \\
\hline 5 & $\mathrm{~A}_{5}$ & 0 & 0 & 1 & 1 & 1 & 0,333 \\
\hline 6 & $\mathrm{~A}_{6}$ & 0 & 0 & 0 & 1 & 0,5 & 0,333 \\
\hline 7 & $\mathrm{~A}_{7}$ & 0 & 1 & 0,5 & 0 & 0 & 0,333 \\
\hline 8 & $\mathrm{~A}_{8}$ & 0 & 0,5 & 0 & 1 & 0,5 & 1 \\
\hline
\end{tabular}

3. Menghitung Nilai S dan R dengan menggunakan persamaan ke 2.

Sebelumnya dilakukan normalisasi terbobot, yaitu nilai matrik yang ternormalisasi dilakukan dengan bobot dari setiap kriteria.

Tabel 4.13 Normalisasi * Bobot

\begin{tabular}{|c|c|c|c|c|c|c|c|}
\hline \multirow{2}{*}{ No } & \multirow{2}{*}{ Alternatif } & \multicolumn{6}{|c|}{ Kriteria } \\
\hline & & $\mathrm{C} 1$ & $\mathrm{C} 2$ & C3 & $\mathrm{C} 4$ & $\mathrm{C} 5$ & C6 \\
\hline 1 & $\mathrm{~A}_{1}$ & $0 * 0,30$ & $0 * 0,25$ & $0 * 0,18$ & $1 * 0,12$ & $0 * 0,10$ & $0,333 * 0,05$ \\
\hline 2 & $\mathrm{~A}_{2}$ & $0 * 0,30$ & $0 * 0,25$ & $0 * 0,18$ & $1 * 0,12$ & $0,5^{*} 0,10$ & $0,333 * 0,05$ \\
\hline 3 & $\mathrm{~A}_{3}$ & $0 * 0,30$ & $1 * 0,25$ & $0 * 0,18$ & $1 * 0,12$ & $0,5^{*} 0,10$ & $0 * 0,05$ \\
\hline 4 & $\mathrm{~A}_{4}$ & $0 * 0,30$ & $0 * 0,25$ & $0 * 0,18$ & $1 * 0,12$ & $0,5^{*} 0,10$ & $1 * 0,05$ \\
\hline 5 & $\mathrm{~A}_{5}$ & $0 * 0,30$ & $0 * 0,25$ & $1 * 0,18$ & $1 * 0,12$ & $1 * 0,10$ & $0,333 * 0,05$ \\
\hline 6 & $\mathrm{~A}_{6}$ & $0 * 0,30$ & $0 * 0,25$ & $0 * 0,18$ & $1 * 0,12$ & $0,5 * 0,10$ & $0,333 * 0,05$ \\
\hline 7 & $\mathrm{~A}_{7}$ & $0 * 0,30$ & $1 * 0,25$ & $0,5 * 0,18$ & $0 * 0,12$ & $0 * 0,10$ & $0,333 * 0,05$ \\
\hline 8 & $\mathrm{~A}_{8}$ & $0 * 0,30$ & $0,5 * 0,25$ & $0 * 0,18$ & $1 * 0,12$ & $0,5^{*} 0,10$ & $1 * 0,05$ \\
\hline
\end{tabular}

Tabel 4.14 Hasil Normalisasi * Bobot

\begin{tabular}{|c|c|c|c|c|c|c|c|}
\hline \multirow{2}{*}{ No } & \multirow{2}{*}{ Alternatif } & \multicolumn{7}{|c|}{ Kriteria } \\
\cline { 2 - 8 } & & $\mathrm{C} 1$ & $\mathrm{C} 2$ & $\mathrm{C} 3$ & $\mathrm{C} 4$ & $\mathrm{C} 5$ & $\mathrm{C} 6$ \\
\hline 1 & $\mathrm{~A}_{1}$ & 0 & 0 & 0 & 0,12 & 0 & 0,01665 \\
\hline 2 & $\mathrm{~A}_{2}$ & 0 & 0 & 0 & 0,12 & 0,05 & 0,01665 \\
\hline 3 & $\mathrm{~A}_{3}$ & 0 & 0,25 & 0 & 0,12 & 0,05 & 0 \\
\hline 4 & $\mathrm{~A}_{4}$ & 0 & 0 & 0 & 0,12 & 0,05 & 0,05 \\
\hline 5 & $\mathrm{~A}_{5}$ & 0 & 0 & 0,18 & 0,12 & 0,10 & 0,01665 \\
\hline 6 & $\mathrm{~A}_{6}$ & 0 & 0 & 0 & 0,12 & 0,05 & 0,01665 \\
\hline 7 & $\mathrm{~A}_{7}$ & 0 & 0,25 & 0,09 & 0 & 0 & 0,01665 \\
\hline 8 & $\mathrm{~A}_{8}$ & 0 & 0,125 & 0 & 0,12 & 0,05 & 0,05 \\
\hline
\end{tabular}

Kemudian melakukan penjumlah dari hasil diatas untuk mendapatkan nilai S. Nilai S didapat dari penjumlahan hasil perkalian bobot kriteria dengan data pada setiap sampel. Berikut ini disajikan perhitungan nilai $\mathrm{S}$.

$$
\begin{array}{ll}
\mathrm{S}(\mathrm{A} 1)=0+0+0+0,12+0+0,01665 & =0,13665 \\
\mathrm{~S}(\mathrm{~A} 2)=0+0+0+0,12+0,05+0,01665 & =0,18665 \\
\mathrm{~S}(\mathrm{~A} 3)=0+0,25+0+0,12+0,05+0 & =0,42 \\
\mathrm{~S}(\mathrm{~A} 4)=0+0+0+0,12+0,05+0,05 & =0,22 \\
\mathrm{~S}(\mathrm{~A} 5)=0+0+0,18+0,12+0,10+0,01665 & =0,41665 \\
\mathrm{~S}(\mathrm{~A} 6)=0+0+0+0,12+0,05+0,01665 & =0,18665 \\
\mathrm{~S}(\mathrm{~A} 7)=0+0,25+0,09+0+0+0,01665 & =0,35665 \\
\mathrm{~S}(\mathrm{~A} 8)=0+0,125+0+0,12+0,05+0,05 & =0,345
\end{array}
$$


Untuk mendapatkan nilai $R_{i}$ menggunakan persamaan ke 3. Nilai $R$ adalah nilai terbesar dari perkalian bobot kriteria dengan data normalisasi dari setiap sampel. Berikut nilai R untuk semua sampel:

$$
\begin{aligned}
& \mathrm{R}(\mathrm{A} 1)=0,12 \\
& \mathrm{R}(\mathrm{A} 2)=0,12 \\
& \mathrm{R}(\mathrm{A} 3)=0,25 \\
& \mathrm{R}(\mathrm{A} 4)=0,12 \\
& \mathrm{R}(\mathrm{A} 5)=0,18 \\
& \mathrm{R}(\mathrm{A} 6)=0,12 \\
& \mathrm{R}(\mathrm{A} 7)=0,25 \\
& \mathrm{R}(\mathrm{A} 8)=0,125
\end{aligned}
$$

Dari hasil perhitungan terhadap nilai S dan R, dapat dilihat pada tabel berikut.

Tabel 4.15 Nilai $S$ dan $R$

\begin{tabular}{|c|c|c|}
\hline Sampel & Nilai S & Nilai $R$ \\
\hline $\mathrm{A}_{1}$ & $\mathbf{0 , 1 3 6 6 5}$ & $\mathbf{0 , 1 2}$ \\
\hline $\mathrm{A}_{2}$ & 0,18665 & 0,12 \\
\hline $\mathrm{A}_{3}$ & 0,42 & $\mathbf{0 , 2 5}$ \\
\hline $\mathrm{A}_{4}$ & 0,22 & 0,12 \\
\hline $\mathrm{A}_{5}$ & $\mathbf{0 , 4 1 6 6 5}$ & 0,18 \\
\hline $\mathrm{A}_{6}$ & 0,18665 & 0,12 \\
\hline $\mathrm{A}_{7}$ & 0,35665 & 0,25 \\
\hline $\mathrm{A}_{8}$ & 0,345 & 0,125 \\
\hline
\end{tabular}

Pada tabel kolom $\mathrm{S}$ dan $\mathrm{R}$ terdapat nilai data yang dipertebal atau ditandai. Kedua data tersebut masing-masing adalah nilai terbesar dan nilai terkecil dari S dan $\mathrm{R}$.

4. Menghitung Indeks VIKOR dengan menggunakan persamaan ke 4.

Sampel dengan nilai $\mathrm{Q}$ terkecil adalah sampel terbaik. Berikut disajikan perhitungan nilai indeks Vikor $(\mathrm{Q})$ :

$$
\begin{aligned}
& \mathrm{Q}(\mathrm{A} 1)=\left[\frac{0,13665-0,13665}{0,41665-0,13665}\right] * 0,5+\left[\frac{0,12-0,12}{0,25-0,12}\right] *(1-0,5) \\
& =\left[\frac{0}{0,28}\right] * 0,5+\left[\frac{0}{0,13}\right] *(0,5) \\
& =(0 * 0,5)+(0 * 0,5) \\
& =0+0 \\
& =0 \\
& \mathrm{Q}(\mathrm{A} 2)=\left[\frac{0,18665-0,13665}{0,41665-0,13665}\right] * 0,5+\left[\frac{0,12-0,12}{0,25-0,12}\right] *(1-0,5) \\
& =\left[\frac{0,05}{0,28}\right] * 0,5+\left[\frac{0}{0,13}\right] *(0,5) \\
& =(0,1785 * 0,5)+(0 * 0,5) \\
& =0,0892+0 \\
& =0,0892 \\
& \mathrm{Q}(\mathrm{A} 3)=\left[\frac{0,42-0,13665}{0,41665-0,13665}\right] * 0,5+\left[\frac{0,25-0,12}{0,25-0,12}\right] *(1-0,5) \\
& =\left[\frac{0,28335}{0,28}\right] * 0,5+\left[\frac{0,13}{0,13}\right] *(0,5) \\
& =(1,0119 * 0,5)+(1 * 0,5) \\
& =0,5055+0,5 \\
& =1,0059 \\
& \mathrm{Q}(\mathrm{A} 4)=\left[\frac{0,22-0,13665}{0,41665-0,13665}\right] * 0,5+\left[\frac{0,12-0,12}{0,25-0,12}\right] *(1-0,5) \\
& =\left[\frac{0,08335}{0,28}\right] * 0,5+\left[\frac{0}{0,13}\right] *(0,5) \\
& =(0,2976 * 0,5)+(0 * 0,5) \\
& =0,1488+0
\end{aligned}
$$




$$
\begin{aligned}
& =0,1488 \\
\text { Q(A5) }=\left[\frac{0,41665-0,13665}{0,41665-0,13665}\right] * 0,5+\left[\frac{0,18-0,12}{0,25-0,12}\right] *(1-0,5) & \\
= & {\left[\frac{0,28}{0,28}\right] * 0,5+\left[\frac{0,06}{0,13}\right] *(0,5) } \\
& =(1 * 0,5)+(0,4615 * 0,5) \\
& =0,5+0,2307 \\
& =0,7307 \\
\text { Q(A6) }= & {\left[\frac{0,18665-0,13665}{0,41665-0,13665}\right] * 0,5+\left[\frac{0,12-0,12}{0,25-0,12}\right] *(1-0,5) } \\
& =\left[\frac{0,05}{0,28}\right] * 0,5+\left[\frac{0}{0,13}\right] *(0,5) \\
& =(0,1785 * 0,5)+(0 * 0,5) \\
& =0,0892+0 \\
& =0,0892 \\
\text { Q(A7) } & =\left[\frac{0,35665-0,13665}{0,41665-0,13665}\right] * 0,5+\left[\frac{0,25-0,12}{0,25-0,12}\right] *(1-0,5) \\
& =\left[\frac{0,22}{0,28}\right] * 0,5+\left[\frac{0,13}{0,13}\right] *(0,5) \\
& =(0,7857 * 0,5)+(1 * 0,5) \\
& =0,3928+0,5 \\
& =0,8928 \\
\text { Q(A8) }= & {\left[\frac{0,345-0,13665}{0,41665-0,13665}\right] * 0,5+\left[\frac{0,125-0,12}{0,25-0,12}\right] *(1-0,5) } \\
& =\left[\frac{0,20835}{0,28}\right] * 0,5+\left[\frac{0,005}{0,13}\right] *(0,5) \\
& =(0,7441 * 0,5)+(0,25 * 0,5) \\
& =0,3720+0,125 \\
& =0,497
\end{aligned}
$$

Dari perhitungan indeks Vikor (Q) di atas, maka diperoleh tabel peringkat indeks sebagai berikut:

Tabel 4.16 Indeks Vikor

\begin{tabular}{|c|l|c|c|}
\hline Alternatif & \multicolumn{1}{|c|}{ Merk AC } & Nilai Q & Peringkat \\
\hline $\mathrm{A}_{1}$ & LG T05NLA & 0 & 1 \\
\hline $\mathrm{A}_{2}$ & PANASONIC PN05RKJ & 0,0892 & 2 \\
\hline $\mathrm{A}_{3}$ & SHARP A5MEY & 1,0059 & 8 \\
\hline $\mathrm{A}_{4}$ & SAMSUNG AR05HCFLAW & 0,1488 & 4 \\
\hline $\mathrm{A}_{5}$ & TAC 09CS/BYTCL & 0,7307 & 6 \\
\hline $\mathrm{A}_{6}$ & DAIKIN FTNE15JEV & 0,0892 & 3 \\
\hline $\mathrm{A}_{7}$ & POLYTRON NEUVA ICE PAC 05VX & 0,8928 & 7 \\
\hline $\mathrm{A}_{8}$ & MITSUBISHI SRK-05CMP-3 & 0,4970 & 5 \\
\hline
\end{tabular}

Pada tabel di atas diperoleh data, bahwa sampel (A1) yaitu Air Conditioner merek LG yang memiliki indeks (nilai Q) terkecil yaitu 0 , sehingga dapat disimpulkan bahwa alternatif terbaik adalah AC merk LG yang menempati peringkat pertama dalam perangkingan menggunakan metode VIKOR.

\section{Kesimpulan}

Dari penelitian yang penulis lakukan, maka dapat di ambil kesimpulan, yaitu:

1. Metode VIKOR dapat diterapkan dalam sistem pendukung keputusan pemilihan AC terbaik dari beberapa kriteria dan alternatif yang ada untuk mengambil sebuah keputusan.

2. Hasil perhitungan menggunakan VIKOR untuk menentukan pemilihan AC terbaik sangat tergantung pada pemberian bobot nilai terhadap kriteria dan sub kriteria yang ada pada tahap penilaian kriteria dan sub kriteria yang akan menghasilkan nilai indeks. 


\section{DAFTAR REFERENSI}

[1] Y. Zai, M. Mesran, B. Nadeak, and I. Saputra, "PENERAPAN TECHNIQUE FOR ORDERS PREFERENCE BY SIMILARITY TO IDEAL SOLUTION (TOPSIS) UNTUK KEPUTUSAN PEMBERIAN KREDIT PADA CALON NASABAH (Studi Kasus : PT. SS Finance)," MEDIA Inform. BUDIDARMA, vol. 1, no. 1, Feb. 2017.

[2] I. Saputra, S. I. Sari, and Mesran, "PENERAPAN ELIMINATION AND CHOICE TRANSLATION REALITY ( ELECTRE ) DALAM PENENTUAN KULKAS TERBAIK," KOMIK (Konferensi Nas. Teknol. Inf. dan Komputer), vol. I, pp. 295-305, 2017.

[3] S. H. Sahir, R. Rosmawati, and K. Minan, "Simple Additive Weighting Method to Determining Employee Salary Increase Rate," Int. J. Sci. Res. Sci. Technol., vol. 3, no. 8, pp. 42-48, 2017.

[4] M. Mesran et al., "The VIKOR Method to Support the Effectiveness of Decisions in Determining Work Incentive Recipients," J. Phys. Conf. Ser., vol. 1175, p. 012043, 2019.

[5] D. Siregar et al., "Multi-Attribute Decision Making with VIKOR Method for Any Purpose Decision," J. Phys. Conf. Ser., vol. 1019, no. 1, 2018.

[6] Y. J. B. Parrangan et al., "The Implementation of VIKOR Method to Improve the Effectiveness of Sidi Learning Graduation,” Int. J. Eng. Technol., vol. 7, pp. 264-267, 2018.

[7] M. Sianturi, S. Wulan, Suginam, Rohminatin, and Mesran, "Implementasi Metode VIKOR Untuk Menentukan Bahan Kulit Terbaik Dalam Pembuatan Ikat Pinggang," J. Ris. Komput., vol. 5, no. 1, pp. 56-60, 2018.

[8] G. \& I. K. P. S. Suwardika, "Penerapan Metode VIKOR pada Pengambilan Keputusan Seleksi Calon Penerima Beasiswa Bidikmisi Universitas Terbuka," vol. 2, no. 1, pp. 24-35, 2018.

[9] H. Tumanggor, M. Haloho, P. Ramadhani, and S. D. Nasution, "Penerapan Metode VIKOR Dalam Penentuan Penerima Dana Bantuan Rumah Tidak Layak Huni," vol. 5, no. 1, pp. 71-78, 2018.

[10] A. Mardani, E. Zavadskas, K. Govindan, A. Amat Senin, and A. Jusoh, "VIKOR Technique: A Systematic Review of the State of the Art Literature on Methodologies and Applications," Sustainability, vol. 8, no. 1, p. 37, Jan. 2016.

[11] Kusrini, Konsep dan Aplikasi Sistem Pendukung Keputusan. 2007.

[12] Efraim Turban and Jay E. Aronson, Decision Support System and Intelligent Systems. 2001.

[13] S. Kusumadewi, S. Hartati, A. Harjoko, and Retantyo Wardoyo, Fuzzy Multi-Attribute Decision Making (FUZZY MADM). 2006.

[14] D. Nofriansyah and S. Defit, Multi Criteria Decision Making (MCDM) pada Sistem Pendukung Keputusan. 2018.

[15] T. Limbong et al., Sistem Pendukung Keputusan: Metode \& Implementasi. Medan: Yayasan Kita Menulis, 2020.

[16] D. Nofriansyah, Konsep Data Mining Vs Sistem Pendukung Keputusan. 2015.

[17] G.-H. Tzeng and J.-J. Huang, Multiple Attribute Decision Making Method And Applications. CRC Press, 2011.

[18] A. Siregar, P. Ginting, M. Mesran, and L. T. Sianturi, "Implementasi Metode Vikor Dalam Pemilihan Supplier Bahan Baku," KOMIK (Konferensi Nas. Teknol. Inf. dan Komputer), vol. I, pp. 132-138, 2017.

[19] S. Datta, "Comparative Study on Application of Utility Concept and Vikor Method for Vendor Selection," AIMS Int. Conf. Value-based Manag., vol. 1, no. 2006, pp. 614-622, 2010.

[20] M. Yazdani and F. R. Graeml, "VIKOR and its Applications," Int. J. Strateg. Decis. Sci., vol. 5, no. 2, pp. 56-83, Apr. 2014.

[21] K. Umam, V. E. Sulastri, T. Andiri, D. U. Sutiksno, and Mesran, "Perancangan Sistem Pendukung Keputusan Penentuan Prioritas Produk Unggulan Daerah Menggunakan Metode VIKOR," J. Ris. Komput., vol. Vol 5, no. 1, pp. 43-49, 2018.

[22] N. Sutrikanti, H. Situmorang, Fachrurrazi, H. Nurdiyanto, and M. Mesran, "Implementasi Pendukung Keputusan Dalam Pemilihan Calon Peserta Cerdas Cermat Tingkat SMA Menerapkan Metode VIKOR," JURIKOM (Jurnal Ris. Komputer), 2018. 